DOI: https://doi.org/10.47405/mjssh.v5i11.542

\begin{tabular}{|c|c|}
\hline Fit & Malaysian Journal of Social Sciences and Humanities (MJSSH) \\
\hline Malaysian Journal of & Volume 5, Issue 11, November 2020 \\
\hline (MJ-ssH) & e-ISSN : 2504-8562 \\
\hline & $\begin{array}{l}\text { Journal home page: } \\
\text { www.msocialsciences.com }\end{array}$ \\
\hline
\end{tabular}

\title{
Hubungan Kaum dalam Kawasan Rukun Tetangga (KRT) di Pantai Barat Sabah
}

\author{
Budi Anto Mohd Tamring ${ }^{1}$, Mohd Sohaimi Esa ${ }^{1}$, Mohd Azri Ibrahim ${ }^{1}$ \\ 1Pusat Penataran Ilmu dan Bahasa, Universiti Malaysia Sabah \\ Correspondence: Budi Anto Mohd Tamring (budi@ums.edu.my)
}

\begin{abstract}
Abstrak
Matlamat penubuhan Rukun tetangga pada awalnya adalah untuk memastikan keselamatan penduduk terjamin tetapi sedikit demi sedikit sehingga kini telah melalui perubahan kepada pelaksanaan atau penganjuran pelbagai program yang lebih bersifat menuntut kerjasama dan interaksi dalam kalangan penduduk. Kewujudan rukun tetangga ini memainkan peranan yang besar dalam mengekalkan hubungan yang baik antara penduduk pelbagai kaum dan agama di sesuatu kawasan petempatan. Kajian ini menggunakan kaedah kuantitatif yang melibatkan seramai 357 orang responden untuk menjelaskan bagaimana hubungan masyarakat pelbagai etnik dan agama di kawasan rukun tetangga yang terlibat. Hasil kajian mendapati, hubungan kaum dan agama di kawasan rukun tetangga di Pantai Barat Sabah adalah baik dan rukun tetangga telah menyebabkan interaksi masyarakat pelbagai etnik dan agama semakin baik.
\end{abstract}

Kata kunci: rukun tetangga, hubungan kaum, Pantai Barat Sabah

\section{Ethnic relation in the Rukun Tetangga (KRT) Area on the West Coast of Sabah}

\begin{abstract}
The goal of the establishment of Rukun tetangga (Community/Neighbourhood Watch) was initially to guarantee the safety of people. However, it has gradually undergone changes to become a mechanism or an organiser of various programs related to cooperation and interaction among members of the community. The existence of neighborly pillar plays a big role in maintaining good relations between the people of various races and religions in a settlement. This study uses a quantitative method that requires a total of 357 respondents to explain the relationship of various ethnic and religious communities in the neighborhood involved. The findings show, the relationship between race and religion in the rukun tetangga area on the West Coast of Sabah is commentable and it has improved interactions among communities of various ethnicity and religious beliefs.
\end{abstract}

Keywords: neighbourhood watch, ethnic relation, Sabah West Coast. 


\section{Pengenalan}

Rukun tetangga diperkenalkan pada tahun 1975 berikutan penguatkuasaan Peraturan-peraturan Perlu mengenai Rukun Tetangga. Skim ini diwujudkan di bawah Peraturan-peraturan Perlu (Rukun Tetangga) dalam Ordinan Darurat 1969 (Jabatan Perpaduan Negara dan Integrasi Nasional, 2020). Pada mulanya Rukun Tetangga ini bertujuan untuk membolehkan rakyat mengawal keselamatan di kawasan kediaman masing-masing dengan mewajibkan masyarakat setempat berumur 18 hingga 55 tahun menjalankan tugas rondaan pada waktu malam. Walau bagaimanapun, pada tahun 1983 kerajaan telah membuat pindaan dengan memberi penekanan kepada konsep kejiranan dalam masyarakat setempat. Pada tahun 2000, pindaan sekali lagi dibuat dengan memberi ruang lebih luas untuk pembangunan masyarakat secara menyeluruh ke arah mewujudkan perpaduan nasional (Mohd Sohaimi, Dayu \& Budi Anto, 2011: 184).

Pindaan selepas itu juga dibuat beberapa kali bertujuan untuk mewujudkan atau mengekalkan hubungan yang harmoni dalam masyarakat serta mengikut tuntutan keperluan semasa. Kawasan kejiranan Rukun Tetangga merupakan lokasi yang memainkan peranan penting dalam melihat kewujudan kesepaduan sosial dipraktikkan dalam kalangan masyarakat di Malaysia (Mohd Syariefudin, Mohd Mahadee, Mansor Mohd, 2013: 72). Malah terdapat laporan menjelaskan bahawa persatuan penduduk, NGO dan Rukun Tetangga menjadi tunjang kepada perpaduan (Bernama, 2019). Justeru itu, kertas kerja ini akan membincangkan hubungan masyarakat di kawasan rukun tetangga khususnya di kawasan Pantai Barat Sabah dalam konteks hubungan antara kaum dan juga hubungan antara agama. Penggunaan singkatan KRT dan RT akan digunakan berulang kali dalam artikel ini yang membawa maksud Kawasan Rukun Tetangga bagi singkatan KRT, manakala Rukun Tetangga bagi singkatan RT.

\section{Sorotan Literatur}

Penduduk Sabah sejak dahulu sering kali diwar-warkan atau dihebahkan oleh ramai pemimpin di Malaysia sebagai negeri yang mempunyai penduduk yang bertoleransi tinggi. Hasil analisis beberapa kajian pengkaji lepas seperti yang dinyatakan dalam artikel bertajuk Hubungan Kaum di Sabah: Satu Pemerhatian Awal (2020) menunjukkan hubungan kaum atau etnik di Sabah sememangnya baik (Budi Anto \& Saidatul, 2020). Beberapa kajian lepas sebelum ini juga menjelaskan bahawa hubungan penduduk di Sabah adalah baik dan tidak pernah berlaku konflik atau pergaduhan antara kaum. Selain itu, hasil beberapa kajian lepas tersebut juga mendapati tahap toleransi penduduk di Sabah adalah tinggi dan prejudis perkauman adalah rendah (Sabihah, 2007; Budi Anto, 2008; Chua, Jasmine \& Lailawati, 2016).

Selain itu, hubungan kaum di Sabah yang baik juga diterjemahkan dalam pelbagai bentuk hubungan termasuk hubungan kekeluargaan melalui ritual budaya masyarakat pribumi yang dikenali sebagai mikorot. Amalan mikorot ialah ritual minum darah untuk menjalinkan hubungan kekeluargaan seperti adik-beradik dengan individu lain tanpa melibatkan perkahwinan. Mikorot ini boleh dilakukan antara individu dengan individu lain yang berbeza kaum mahupun agama. Amalan ritual mikorot ini walaupun agak kurang dilakukan pada masa kini, tetapi amalan ini yang sejak dahulunya berlaku di Sabah menunjukkan etnik pribumi di Sabah memiliki tahap toleransi etnik yang tinggi kerana mereka boleh menerima seseorang yang berbeza budaya dan agama menjadi sebahagian daripada keluarga mereka hanya melalui ritual budaya (Budi Anto, 2018). Dalam konteks lain pula, hubungan masyarakat di Sabah juga dikatakan baik dengan melihat amalan kahwin campur yang tinggi. Amalan kahwin campur ini akan mewujudkan generasi masyarakat yang lebih terbuka, selain merupakan petanda keadaan masyarakat yang harmoni atau masyarakat yang mempunyai toleransi yang tinggi (Suraya, Budi Anto \& Khadijah, 2016; Sharifah, 2019; Budi Anto \& Saidatul, 2020). Masyarakat di Sabah yang dilihat mempunyai hubungan kaum yang baik juga dikatakan mempunyai toleransi yang tinggi dalam kehidupan beragama. Kajian lepas juga menunjukkan sikap penerimaan dan akomodatif mencatatkan respons tertinggi serta kesediaan penganut pelbagai agama menangani perbezaan dan konflik secara harmonis (Suraya, Budi Anto, Nur Farhana, Siti Aidah \& Halina Sendera, 2019). 
Hubungan kaum yang baik di Sabah dinyatakan dalam beberapa kajian lepas di atas dilihat secara umumnya menjelaskan masyarakat di Sabah berinteraksi dengan baik dan harmoni. Justeru itu, kajian ini sekali lagi cuba untuk menjelaskan hubungan masyarakat di Sabah tetapi memfokuskan kawasan rukun tetangga. Ini kerana seperti yang telah dimaklumkan sebelum ini rukun tetangga telah melaksanakan pelbagai program yang membentuk kerjasama dan penglibatan masyarakat setempat yang sudah tentunya juga mewujudkan hubungan yang baik antara penduduk. Sekiranya hubungan kaum di Sabah ini sememangnya baik, dan pelaksanaan program rukun tetangga juga menambahkan lagi keadaan yang baik tersebut, maka sudah tentunya penduduk di kawasan rukun tetangga juga mempunyai hubungan yang baik.

Beberapa kajian lepas mengenai rukun tetangga juga telah dibuat di Malaysia. Di Sabah kajian mengenai rukun tetangga telah dibuat oleh Norwahidah (2016) yang bertajuk Makna Rasa Selamat Komuniti Malaysia dalam Program Skim Rondaan Sukarela: Kajian kes KRT Taman Putera Jaya, Kota Kinabalu, Sabah. Berdasarkan hasil kajian tersebut didapati bahawa RT telah membawa kepada pengertian terhadap makna rasa selamat dalam kalangan komuniti bagi mencegah aktiviti jenayah dan menangani isu keselamatan awam. Keadaan ini membantu komuniti memahami masalah harian yang dihadapi dan dizahirkan melalui penglibatan secara aktif dalam organisasi sukarelawan keselamatan komuniti. Data kajian diperoleh daripada 10 orang informan melalui sesi temu bual mendalam dan perbincangan kumpulan secara tak formal. Hasil kajian mendapati pengertian selamat yang difahami oleh komuniti di Sabah bukan sahaja melibatkan aspek luaran atau fizikal semata-mata, tetapi juga aspek psikologi dan emosional yang turut dipengaruhi oleh lokaliti dan budaya. Manakala kajian, Mohd Sohaimi, Budi Anto, Yusten, Mohd Azri, Dayu, Siti Aidah \& Sharifah (2019) bertajuk Rukun Tetangga dalam Konteks Kesepaduan Sosial Di Pantai Barat Sabah: Satu Tinjauan Awal pula menjelaskan tentang bagaimana aktiviti-aktiviti yang dilaksanakan dalam KRT mampu mewujudkan hubungan yang baik dalam masyarakat. Kajian ini menggunakan kaedah temu bual dengan memberi fokus kepada pemimpin-pemimpin KRT di kawasan Pantai Barat Sabah. Hasil kajian ini menjelaskan bahawa aktiviti KRT yang dilaksanakan berupaya mewujudkan kesepaduan sosial dalam masyarakat.

Pertambahan jumlah ahli KRT di Sabah juga dikatakan menandakan bahawa terdapat kesedaran di kalangan rakyat mengenai KRT dalam masyarakat. Timbalan Menteri di Jabatan Perdana Menteri (Perpaduan Negara dan Keselamatan Sosial), Datuk Dr Md Farid Bin Md Rafik berkata pertambahan ini sesuai kerana KRT mempunyai peranan penting dalam memupuk semangat perpaduan nasional tanpa mengira bangsa, budaya, agama dan ideologi politik. Timbalan Menteri di Jabatan Perdana Menteri tersebut menyatakan jumlah anggota KRT pada masa ini mencapai 1056 yang di tubuhkan di Sabah. Keadaan ini jelas sekali memperlihatkan peranan KRT penting dan sangat diperlukan dalam masyarakat, bukan sahaja untuk tujuan mengadakan program kemasyarakatan tetapi penting juga untuk membantu dalam aspek keamanan (Clarence, 2019). Kesedaran masyarakat mengenai kepentingan bersama menjaga keselamatan tempat kediaman menerusi Kelab Rukun Tetangga (KRT), secara tidak langsung mewujudkan suasana harmoni dalam kawasan komuniti masing-masing (Abdul, 2018).

Selain di Sabah, terdapat juga kajian yang dibuat di negeri-negeri lain. Sebagai contoh kajian, Mohd. Taib, Izaidin, Raja Roslan, Norliah, Zawiah \& Noor Maslian (2008) yang bertajuk City As An Urban Social Diversity: A Case Study Of Rukun Tetangga In Kuala Lumpur And Selangor adalah kajian yang memberi tumpuan terhadap tahap pengetahuan, persepsi dan penerimaan masyarakat terhadap program yang dianjurkan oleh Rukun Tetangga. Hasil kajian tersebut menunjukkan bahawa tahap pengetahuan, persepsi dan penerimaan masyarakat terhadap program yang dianjurkan oleh RT umumnya tinggi. Ini bermakna selain daripada tahap penerimaan yang tinggi terhadap RT, responden kajian juga mempunyai tahap pengetahuan yang tinggi dan persepsi yang baik terhadap RT. Hasil kajian ini boleh digunakan sebagai indikator yang menunjukkan bahawa pelaksanaan rukun tetangga selama ini membuahkan hasil dan mencapai objektif yang digariskan. RT yang dilaksanakan juga meningkatkan keharmonian dan menyumbang kepada integrasi nasional.

Manakala kajian Hamidah, (2014) pula adalah bertajuk, "Kepimpinan Rukun Tetangga: Satu kajian Kes di Kawasan Rukun Tetangga Kampung Malaysia Raya, Cheras, Kuala Lumpur.” Hasil kajian tersebut mendapati, KRT yang kurang aktif sering dikaitkan dengan kegagalan pengerusi memainkan peranan mereka sebagai pemimpin yang berkesan. Kajian ini menggunakan borang soal selidik yang 
melibatkan seramai 320 orang responden terdiri daripada jiran muda, jiran wanita, rukun tetangga dan jiran usia emas. Dapatan kajian menunjukkan bahawa pengerusi RT mempunyai karakter, tingkah laku dan memahami peranan sebagai seorang pemimpin berdasarkan dimensi tugas dan pertimbangan pada tahap tinggi. Kajian ini juga mendapati bahawa pengerusi RT mengamalkan gaya kepimpinan demokratik dalam memastikan matlamat untuk menyatupadukan masyarakat dapat dicapai. Gaya ini merupakan gaya paling berkesan untuk memupuk kepuasan yang tinggi dalam kalangan anggotanya dan dapat meningkatkan prestasi organisasi RT ke arah kecemerlangan.

Selain kepimpinan, terdapat juga kajian berkaitan dengan isu jantina dalam KRT. Misalnya, Penerimaan Masyarakat Terhadap Aktiviti Rukun Tetangga Mengikut Jantina oleh Ahmad Zaharuddin \& Nur Syafiqah (2016) di negeri Kedah. Secara umumnya, kajian tersebut melihat tahap penerimaan masyarakat terhadap RT merangkumi penglibatan individu dalam RT, kepimpinan dalam RT, interaksi antara sesama ahli RT dan mengenal pasti RT dapat diterima oleh masyarakat terutama melalui penerimaan dari segi jantina dan kefahaman penduduk. Seramai 1866 orang responden telah dipilih berpandukan senarai Rukun Tetangga yang berdaftar yang didapati dari Jabatan Perpaduan Negara dan Integrasi Nasional (JPNIN). Dapatan kajian menunjukkan penerimaan lelaki lebih tinggi menyatakan beban kerja bukanlah penghalang daripada melakukan aktiviti KRT berbanding perempuan. Begitu juga mengenai hubungan erat antara responden dengan penduduk. Walaupun responden lelaki dan perempuan didapati majoritinya mempunyai hubungan yang sangat erat dengan persatuan penduduk tetapi, responden lelaki didapati lebih menonjol berbanding perempuan.

Kajian Mohd Syariefudin, Mansor, Ahmad Rizal \& Faridah (2017), yang bertajuk Social Cohesion In Rukun Tetangga (Neighbourhood Watch) In Hulu Langat, Selangor Malaysia pula, adalah cuba melihat perpaduan sosial dalam masyarakat, terutama di kawasan kejiranan RT. Kawasan kajian melibatkan Kajang, Ampang, Cheras, Beranang, Hulu Langat, Semenyih dan Bangi. Kajian ini telah menggunakan konsep kohesi sosial yang dibawa oleh Jenson (1998) dan Paul (2000). Terdapat enam dimensi yang digunakan untuk mengukur kohesi sosial yang melibatkan sebanyak 588 orang responden kajian. Hasil kajian menunjukkan kohesi sosial bagi setiap dimensi yang diukur adalah mempunyai nilai yang positif dan tinggi bagi semua etnik yang dikaji.

Seterusnya, kajian Mohd Syariefudin, Mazdi, Mohd Marzuqi, Muhammad Akramin dan Khairul Ghufran (2020) yang bertajuk Penubuhan Rukun Tetangga Di Malaysia daripada Perspektif Islam adalah kajian yang terbaru tentang rukun tetangga. Kajian ini lebih bersifat menjelaskan sejarah penubuhan rukun tetangga, fungsi rukun tetangga dan menjelaskan aktiviti rukun tetangga bagi menggalakkan perpaduan daripada perspektif Islam. Aktiviti penggalak perpaduan yang dijelaskan meliputi lawati jiran, menghulurkan bantuan, mengenali jiran dan aktiviti bersama. Dalam kajian tersebut, penyelidik juga mengatakan bahawa RT merupakan mekanisme penting untuk menyatukan penduduk pelbagai etnik yang berbeza.

Beberapa kajian lepas yang telah dijelaskan di atas tidak begitu memberikan fokus mengenai keadaan hubungan kaum atau hubungan masyarakat di sesuatu kawasan rukun tetangga khususnya di negeri Sabah. Walaupun ada kajian yang menjelaskan tentang aktiviti KRT mewujudkan hubungan yang baik dalam masyarakat tetapi penerangan mengenai keadaan hubungan masyarakat secara khusus di kawasan rukun tetangga tidak begitu menonjol dalam kajian-kajian lepas di Sabah. Keadaan ini berlaku disebabkan kajian mengenai rukun tetangga masih terlalu kurang dibuat di negeri Sabah. Kajian seperti ini selain bertujuan memahami tentang kepentingan rukun tetangga, ia juga secara langsung dapat memahami hubungan antara kaum di sesuatu kawasan. Kajian seperti ini penting kerana pola kependudukan secara umumnya di kawasan pekan atau bandar sering kali menunjukkan percampuran kaum dan agama yang tinggi. Percampuran yang tinggi ini sekiranya tidak diuruskan dengan baik boleh jadi akan menimbulkan konflik dan persaingan dalam kalangan penduduk. Ini kerana nilai etnik sering kali akan bertambah menjadi lebih ekstrem dengan kemunculan perasaan etnosentrisme yang melihat kelompok etnik sendiri lebih baik berbanding kumpulan etnik lain (Saidatul, 2013:6). Walaupun beberapa kajian lepas menjelaskan bahawa hubungan kaum di Sabah adalah baik, tetapi kajian ini sekali lagi akan membuktikan pandangan tersebut sama ada benar ataupun tidak melalui penjelasan hasil kajian ini yang lebih memfokuskan hubungan kaum di kawasan RT di bahagian Pantai Barat Sabah. 


\section{Metod Kajian}

Kajian ini menggunakan kaedah kuantitatif dengan menggunakan soal-selidik sebagai alat pengumpulan data. Seramai 357 orang responden telah terpilih dalam kajian ini. Jumlah responden kajian ini lebih tinggi berbanding jumlah responden dalam kajian Hamidah Abu Bakar yang telah dibuat di Kuala Lumpur sebelum ini pada tahun 2014. Soal-selidik telah diedarkan kepada responden oleh penyelidik dan juga dengan bantuan pembantu penyelidik yang dilantik. Kawasan kajian adalah di kawasan pantai Barat Sabah tetapi hanya tertumpu di daerah Kota Kinabalu dan Penampang sebagai fokus utama. Ini kerana kawasan ini merupakan daerah yang paling maju berbanding kawasan lain dan melibatkan kepadatan penduduk yang tinggi dari segi petempatan di kawasan Pantai Barat Sabah. Walau bagaimanapun, terdapat juga beberapa orang responden yang terpilih dari kawasan selain Kota Kinabalu dan Penampang sebagai responden kajian. Responden tersebut kebanyakannya menetap di kawasan sempadan atau kawasan bersebelahan dengan daerah Penampang dan Kota Kinabalu tetapi masih lagi berada dalam kawasan Pantai Barat Sabah.

\section{Hasil Kajian}

Sebelum menerangkan tentang hubungan kaum dalam kawasan rukun tetanga yang dikaji, terlebih dahulu dijelaskan beberapa aspek yang melibatkan latar belakang dan demografi kawasan kajian. Pertama sekali adalah tentang kawasan RT yang terpilih dalam kajian ini iaitu melibatkan 27 kawasan. 27 KRT ini dipilih berdasarkan maklumat yang diberikan oleh Jabatan Perpaduan Negara dan Integrasi Nasional Negeri Sabah (Jabatan Perpaduan Negara dan Integrasi Nasional Sabah, 2018). Pada awalnya bilangan KRT yang dipilih adalah 30 kawasan tetapi akhirnya hanya melibatkan 27 kawasan sahaja kerana tiga daripada KRT yang telah dicadangakan pada peringkat awal didapati tidak akitf ataupun sudah dibubarkan. Oleh yang demikian beberapa responden kajian juga dipilih dari kawasan lain-lain selain dari 27 kawasan yang sudah ditetapkan. Kesemua 27 KRT yang terpilih ini adalah dalam daerah Penampang dan Kota Kinabalu seperti yang ditunjukkan dalam Jadual 1.

Jadual 1: Kawasan Rukun Tetangga (Kawasan kajian)

\begin{tabular}{ll}
\hline \multicolumn{1}{c}{ Kawasan Rukun Tetangga (Kawasan kajian) } \\
\hline 1. Taman Antarabangsa Likas & 15. Tebobon \\
2. Taman Khidmat & 16. Putaton \\
3. Taman Dixon Goodwill Committee & 17. Penampang Proper \\
4. Taman Cerah & 18. Nossob Baru \\
5. Taman Jaya Diri & 19. Bukitas \\
6. Taman Malawa & 20. Kolupis \\
7. Taman Putera Perdana & 21. Terawi \\
8. Taman Keramat & 22. Matambai \\
9. Damai & 23. Inobong \\
10. Kepayan Ridge & 24. Ramayah \\
11. Tanjung Aru & 25. Taman Hiburan \\
12. Kg. Kionsom/Kobuni & 26. Sarapung \\
13. Kg.Unggun Jaya & 27. Nagasiba \\
14. Luyang & 28. Lain-Lain \\
\hline
\end{tabular}

Seterusnya dari segi demografi penduduk pula, komposisi penduduk di kawasan Kota Kinabalu dan Penampang seperti yang ditunjukkan dalam Jadual 2 memperlihatkan percampuran yang agak tinggi melibatkan beberapa kategori etnik tempatan mahupun warga asing. Percampuran yang tinggi ini boleh jadi akan membentuk hubungan yang baik ataupun hasil pengalaman interaksi yang berlaku boleh jadi juga akan membentuk hubungan yang tidak baik. Oleh sebab itulah, maka kajian ini amat sesuai untuk melihat hubungan antara masyarakat pelbagai budaya di kawasan RT yang terlibat. 
DOI: https://doi.org/10.47405/mjssh.v5i11.542

Jadual 2: Komposisi Penduduk Kawasan Kajian

\begin{tabular}{lcc}
\hline \multirow{2}{*}{ Kumpulan Etnik } & \multicolumn{2}{c}{ Daerah } \\
\cline { 2 - 3 } & Kota Kinabalu & Penampang \\
\hline Melayu & 36918 & 6004 \\
Kadazandusun & 71335 & 43742 \\
Bajau & 74731 & 9422 \\
Murut & 2554 & 1429 \\
Bumi lain & 60512 & 13089 \\
Cina & 96852 & 28636 \\
India & 2291 & 652 \\
Lain-lain & 5625 & 2085 \\
Asing & 112145 & 20854 \\
Jumlah & $\mathbf{4 6 2 9 6 3}$ & $\mathbf{1 2 5 9 1 3}$ \\
\hline Sum
\end{tabular}

Sumber: Buku Tahunan Perangkaan Sabah 2014.

Jadual 3 menunjukkan maklumat yang diperolehi daripada responden kajian berkaitan komposisi penduduk di kawasan petempatan mereka. Jika dilihat dari segi percampuran kaum, $89.9 \%$ mengatakan kawasan petempatan mereka adalah bercampur pelbagai kaum. Ini bermakna percampuran kaum yang ditunjukkan bersesuaian dengan komposisi penduduk di Kota Kinabalu dan Penampang yang juga menunjukkan percampuran pelbagai kaum yang tinggi.

Jadual 3: Penduduk Kawasan Bercampur Kaum

\begin{tabular}{lcc}
\hline Kategori Jawapan & Jumlah & Peratusan \\
\hline ya & 321 & 89.9 \\
tidak & 19 & 5.3 \\
tidak pasti & 17 & 4.8 \\
Total & 357 & 100.0 \\
\hline
\end{tabular}

Jika dilihat dari segi demografi berasaskan komposisi agama pula, seperti yang ditunjukkan dalam Jadual 4, didapati kawasan petempatan responden yang terlibat juga menunjukkan percampuran yang tinggi melibatkan penduduk pelbagai agama. $91.6 \%$ responden kajian mengatakan kawasan petempatan mereka adalah bercampur antara penduduk pelbagai agama.

Jadual 4: Penduduk Kawasan Bercampur Agama

\begin{tabular}{lcc}
\hline Kategori Jawapan & Jumlah & Peratusan \\
\hline ya & 327 & 91.6 \\
tidak & 20 & 5.6 \\
tidak pasti & 10 & 2.8 \\
Total & 357 & 100.0 \\
\hline
\end{tabular}

Selain itu, dalam konteks percampuran kelas (golongan miskin dan kaya) juga didapati adalah tinggi di kawasan petempatan responden. Keadaan ini berlaku mungkin disebabkan kebanyakan KRT yang terlibat adalah di kawasan petempatan bandar dan pekan atau kawasan petempatan yang berhampiran dengan pusat bandar dan pekan. Kawasan perumahan responden melibatkan pelbagai jenis kawasan petempatan iaitu melibatkan jenis kawasan petempatan kampung dan juga kawasan petempatan moden seperti taman-taman perumahan di kawasan pekan dan bandar. Pola petempatan sedemikian secara langsung juga melibatkan penduduk yang mempunyai kuasa beli atau kelas ekonomi yang berbezabeza. Sebanyak $76.8 \%$ responden kajian menyatakan bahawa kawasan petempatan mereka bercampur antara golongan kelas miskin dan kaya. 
DOI: https://doi.org/10.47405/mjssh.v5i11.542

Jadual 5: Penduduk Kawasan Bercampur kelas (miskin dan kaya)

\begin{tabular}{lcc}
\hline Kategori Jawapan & Jumlah & Peratusan \\
\hline ya & 274 & 76.8 \\
tidak & 49 & 13.7 \\
tidak pasti & 34 & 9.5 \\
Total & 357 & 100.0 \\
\hline
\end{tabular}

Penjelasan di atas yang melibatkan komposisi kaum dan agama mahupun kelas di kawasan kajian secara tidak langsung memberikan gambaran bahawa, hubungan masyarakat boleh menjadi tegang ataupun wujud persaingan disebabkan oleh percampuran yang tinggi. Ini kerana, banyak masyarakat di seluruh dunia berhadapan konflik disebabkan oleh perbezaan kaum dan agama. Walau bagaimanapun, beberapa kajian lepas membuktikan bahawa negeri Sabah merupakan negeri yang mempunyai penduduk yang bertoleransi tinggi. Maka sebab itulah dalam konteks kajian ini, peranan KRT akan dijelaskan dengan salah satunya memfokuskan peranan KRT dalam menambahkan lagi pengukuhan hubungan antara penduduk pelbagai kaum dan agama di Sabah. Malah terdapat laporan sebelum ini menjelaskan bahwa rukun tetangga mampu tingkatkan kefahaman penduduk mengenai perpaduan (Bernama, 2009).

Berdasarkan maklumat yang diperolehi daripada responden kajian, didapati KRT mempunyai peranan yang tinggi mengukuhkan lagi hubungan penduduk di kawasan Pantai Barat Sabah. Jadual 6 menunjukkan 79.6\% responden mengatakan aktiviti KRT yang dilaksanakan mengukuhkan hubungan penduduk pelbagai kaum, agama dan kelas di kawasan kajian. Dapatan kajian ini memberikan gambaran bahawa hubungan antara pelbagai kaum dan agama di Sabah yang dikatakan baik sebelum ini bertambah semakin baik dan kukuh dengan pelaksanaan aktiviti KRT. Penduduk setempat secara langsung akan terlibat dengan aktiviti KRT kerana kebiasaannya aktiviti yang dilaksanakan meliputi pelbagai program yang mampu menarik penglibatan pelbagai lapisan masyarakat daripada golongan kanak-kanak, remaja, dewasa mahupun warga emas. Kebiasaanya aktiviti KRT yang dijalankan bukan sahaja melibatkan aktiviti rondaan semata mata tetapi juga melibatkan aktiviti lain seperti sukan, gotong-royong dan penganjuran pelbagai program yang melibatkan berkongsi perayaan mahupun aktiviti penganjuran bengkel atau kursus-kursus kemahiran kepada penduduk.

Jadual 6: Aktiviti KRT Mengukuhkan Hubungan Penduduk Pelbagai Kaum, Agama, Kelas

\begin{tabular}{lcc}
\hline Kategori Jawapan & Jumlah & Peratusan \\
\hline ya & 284 & 79.6 \\
tidak & 30 & 8.4 \\
tidak pasti & 43 & 12.0 \\
Total & 357 & 100.0 \\
\hline
\end{tabular}

Untuk mengetahui adakah kawasan petempatan responden yang terlibat mempunyai hubungan kaum yang baik antara penduduknya maka perlu juga dijelaskan adakah wujud kecenderungan memilih kaum tertentu dalam pemilihan pemimpin KRT di kawasan petempatan mereka. Penjelasan ini perlu kerana terdapat KRT sebelum ini dilaporkan mempunyai jawatankuasa kawasan rukun tetangga yang boleh menjadi contoh terbaik perpaduan kaum dan etnik kerana keahlian jawatankuasa tersebut yang melibatkan pelbagai kaum yang merangkumi Melayu, Cina, India dan Kadazan (Mohammad Ishak, 2017). Hasil kajian seperti yang ditunjukkan dalam jadual 7 memperlihatkan isu identiti etnik bukanlah sesuatu yang menjadi masalah besar apabila melibatkan pelantikan pemimpin KRT. Hanya 23.5\% mengatakan isu tersebut wujud. Ini bermakna, isu tentang persaingan antara masyarakat pelbagai etnik adalah rendah. Malah 37.3\% mengatakan tidak pasti, bermakna isu etnik bukan sesuatu isu yang besar dalam kawasan petempatan responden kerana mereka tidak pasti isu tersebut berlaku. Sekiranya isu etnik adalah isu yang besar, sudah tentunya majoriti masyarakat tahu dan sedar tentang isu tersebut tetapi sebaliknya responden lebih ramai yang mengatakan tidak dan tidak pasti. Keadaan ini menunjukkan hubungan antara kaum secara umumnya adalah baik. 
DOI: https://doi.org/10.47405/mjssh.v5i11.542

Jadual 7: Identiti Etnik Menjadi Faktor Pemilihan Pemimpin KRT

\begin{tabular}{lcc}
\hline Kategori Jawapan & Jumlah & Peratusan \\
\hline ya & 84 & 23.5 \\
tidak & 140 & 39.2 \\
tidak pasti & 133 & 37.3 \\
Total & 357 & 100.0 \\
\hline
\end{tabular}

Demikian juga reaksi responden apabila diajukan mengenai identiti agama sama ada menjadi faktor penting dalam pemilihan pemimpin KRT di kawasan mereka ataupun sebaliknya. Hanya $24.6 \%$ sahaja menyatakan bahawa identiti agama menjadi faktor penting manakala 40.6.\% mengatakan tidak. Dapatan kajian ini juga menunjukkan bahawa isu identiti agama bukanlah sesuatu isu yang agak besar apabila dikaitkan dengan pemilihan pemimpin KRT di kawasan petempatan responden. Malah dikukuhkan lagi apabila $34.7 \%$ responden mengatakan tidak pasti. Jawapan tidak pasti seperti juga yang telah dijelaskan di atas menggambarkan bahawa isu agama bukanlah isu yang besar dalam pemilihan pemimpin KRT kerana agak ramai responden yang mengatakan tidak pasti keadaan tersebut berlaku. Keadaan ini juga secara langsung memberi gambaran bahawa penduduk di kawasan kajian mempunyai hubungan yang baik bukan sahaja merentasi pergaulan antara etnik tetapi juga agama.

Jadual 8: Identiti Agama Menjadi Faktor Pemilihan Pemimpin KRT

\begin{tabular}{lcc}
\hline Kategori Jawapan & Jumlah & Peratusan \\
\hline ya & 88 & 24.6 \\
tidak & 145 & 40.6 \\
tidak pasti & 124 & 34.7 \\
Total & 357 & 100.0 \\
\hline
\end{tabular}

Dalam konteks kerjasama antara pemimpin KRT pula, juga menunjukkan hanya $27.7 \%$ sahaja responden yang mengatakan wujud masalah di kawasan petempatan mereka. Responden lain mengatakan tidak wujud masalah dan ada juga responden yang mengatakan tidak pasti berlaku masalah kerjasama antara pemimpin KRT di kawasan mereka. Responden yang mengatakan tidak dan tidak pasti mewakili $72.3 \%$ daripada jumlah keseluruhan responden. Dapatan ini menunjukkan bahawa, kerjasama dalam kepimpinan KRT walaupun ada masalah tetapi masalah tersebut bukanlah masalah yang besar dalam masyarakat. Masalah tersebut boleh jadi adalah disebabkan oleh pelbagai faktor antaranya perbezaan pendapat antara pemimpin dan beberapa faktor yang lain.

Jadual 9: Wujud Masalah Kerjasama Dalam Kepimpinan KRT

\begin{tabular}{lcc}
\hline Kategori Jawapan & Jumlah & Peratusan \\
\hline ya & 99 & 27.7 \\
tidak & 130 & 36.4 \\
tidak pasti & 128 & 35.9 \\
Total & 357 & 100.0 \\
\hline
\end{tabular}

Selain itu, kerjasama antara masyarakat pelbagai etnik, agama dan kelas dalam kawasan petempatan responden juga didapati adalah baik. Secara keseluruhannya, sebanyak 33.1\% responden mengatakan tidak wujud masalah kerjasama antara penduduk di kawasan petempatan mereka. Manakala 36.4\% mengatakan tidak pasti. Kedua-dua kategori responden ini mewakili $69.5 \%$ responden secara keseluruhan. Hanya $30.5 \%$ yang mengatakan wujud masalah. Walaupun penemuan kajian ini mendapati wujud masalah tetapi peratusan itu masih kecil dan majoritinya mengatakan tidak timbul masalah dan tidak pasti sama ada wujdu masalah kerjasama antara penduduk wujud. Maka dengan itu masalah kerjasama antara penduduk bukanlah perkara yang menimbulkan masalah besar dalam masyarakat.

Jadual 10: Wujud Masalah Kerjasama Antara Pelbagai Etnik, 
Agama, Dan Kelas

\begin{tabular}{lcc}
\hline Kategori Jawapan & Jumlah & Peratusan \\
\hline ya & 109 & 30.5 \\
tidak & 118 & 33.1 \\
tidak pasti & 130 & 36.4 \\
Total & 357 & 100.0 \\
\hline
\end{tabular}

Kebiasaannya masalah yang timbul dalam KRT berkemungkinan besar adalah isu penyertaan aktiviti yang kurang mendapat sambutan dan kurang kerjasama daripada penduduk. Ini kerana kebanyakan semua aktiviti KRT adalah bersifat sukarela dan bergantung kepada penaja untuk menangung kos program yang dilaksanakan malah kebanyakannya juga memerlukan sumbangan daripada penduduk setempat. Selain itu, jika dilihat dari segi tempoh penglibatan responden seperti yang ditunjukkan dalam Jadual 11 pula, 84.6\% responden kajian didapati terlibat dengan RT dan peratusan penglibatan ini adalah tinggi walaupun tempoh masa penglibatan adalah berbeza-beza. Hanya 15.4 yang tidak pernah terlibat dalam KRT. Penglibatan responden kajian terhadap RT yang tinggi ini memberikan juga gambaran bahawa isu kerjasama dalam masyarakat di Kawasan RT adalah bukan merupakan isu besar. Bahkan, walaupun wujud beberapa masalah kerjasama antara penduduk, tetapi dapatan ini secara umumnya menunjukkan hubungan antara penduduk di kawasan kajian masih dalam keadaan yang baik dan harmoni kerana dalam masa yang sama, secara keseluruhannya responden juga mengatakan mereka merasa selamat di kawasan petempatan mereka.

Jadual 11: Tempoh Penglibatan dalam KRT

\begin{tabular}{lcc}
\hline Kategori Jawapan & Jumlah & Peratusan \\
\hline Kurang 1 tahun & 65 & 18.2 \\
1-5 tahun & 158 & 44.3 \\
6-10 tahun & 56 & 15.7 \\
11-15 tahun & 15 & 4.2 \\
16-20 tahun & 8 & 2.2 \\
tidak pernah terlibat & 55 & 15.4 \\
Total & 357 & 100.0 \\
\hline
\end{tabular}

Jadual 12 menunjukkan $85.4 \%$ responden mengatakan mereka merasa selamat di kawasan petempatan mereka. Walaupun petempatan mereka bercampur kaum, agama, kelas ekonomi, dan terdapat sedikit isu berkaitan kerjasama antara penduduk tetapi keadaan tersebut tidak membimbangkan mereka. Malah keadaan tersebut tidak mendatangkan kesan yang besar terhadap hubungan antara mereka. Ini kerana mereka majoritinya merasakan selamat di kawasan petempatan mereka. Perasaan rasa selamat ini memberi gambaran bahawa penduduk di kawasan RT mempunyai kepercayaan yang tinggi terhadap jiran tetangga mereka dan saling bergantungan antara satu sama lain walaupun mereka berbeza budaya mahupun agama. Keadaan ini merupakan satu petunjuk kepada keadaan masyarakat yang harmoni.

Jadual 12: Merasa Selamat di kawasan RT

\begin{tabular}{lcc}
\hline Kategori Jawapan & Jumlah & Peratusan \\
\hline ya & 305 & 85.4 \\
tidak & 17 & 4.8 \\
tidak pasti & 35 & 9.8 \\
Total & 357 & 100.0 \\
\hline
\end{tabular}




\section{Perbincangan Kajian}

Secara keseluruhannya, dapatan kajian menunjukkan hubungan antara kaum di kawasan petempatan responden adalah baik. Dapatan ini agak selari dengan dapatan kajian-kajian lepas mengenai hubungan antara kaum di Sabah adalah baik. Dalam konteks kajian ini hubungan kaum yang dijelaskan merangkumi tiga konteks iaitu hubungan antara penduduk di kawasan RT, hubungan antara penduduk dengan pemimpin KRT dan kesan pelaksanaan aktiviti KRT terhadap mengukuhkan hubungan kaum di kawasan petempatan penduduk.

\section{Hubungan Kaum di Kawasan RT}

Hubungan kaum seperti yang telah dijelaskan di kawasan petempatan responden didapati adalah baik melangkaui sempadan etnik atau kaum, agama mahupun kelas. Meskipun percampuran penduduk di kawasan petempatan responden adalah tinggi dari segi percampuran kaum, agama dan kelas ekonomi tetapi hubungan antara penduduk adalah harmoni. Malah responden merasakan selamat menetap di kawasan kediaman mereka. Rasa selamat di kawasan petempatan mereka walaupun dikelilingi oleh kejiranan yang bercampur kaum dan agama merupakan satu tanda kepercayaan yang tinggi dan menunjukkan saling kebergantungan antara mereka wujud. Dapatan ini bersesuaian dengan kajiankajian lepas yang menyatakan bahawa toleransi kaum di Sabah adalah tinggi dan masyarakatnya juga hidup dalam keadaan yang baik dan harmoni.

\section{Peranan Aktiviti KRT dalam Mengukuhkan Hubungan antara Penduduk}

Hubungan kaum di kawasan RT dijelaskan berdasarkan maklum balas responden terhadap aktiviti KRT yang dilaksanakan di kawasan petempatan mereka. Responden secara umumnya mengatakan bahawa aktiviti KRT yang dilaksanakan mengukuhkan lagi hubungan antara penduduk setempat yang terdiri daripada pelbagai kaum, agama mahupun kelas ekonomi. Penemuan kajian ini memberikan gambaran bahawa, pelaksanaan KRT oleh kerajaan merupakan satu mekanisme yang baik untuk mewujudkan integrasi dalam kalangan masyarakat dan perlu diteruskan pada masa akan datang dan dikembangkan lagi di kawasan-kawasan petempatan lain di seluruh Malaysia. Pelaksanaan aktiviti KRT di sesuatu kawasan petempatan secara tidak langsung akan menggalakkan penduduk untuk bersua dan berinteraksi kerana aktiviti yang dijalankan kebanyakannya adalah untuk menjaga keselamatan dan kepentingan bersama. Malah dalam kajian ini juga menunjukkan majoriti responden pernah terlibat dengan KRT. Keadaan ini menunjukkan mereka tiada masalah untuk menjalin kerjasama mahupun melakukan aktiviti RT bersama-sama walaupun berbeza kaum dan agama.

\section{Hubungan Masyarakatdengan Pemimpin KRT}

Dalam konteks hubungan masyarakat dengan kepimpinan KRT pula, juga didapati menunjukkan hubungan yang baik merentasi kaum mahupun agama. Walaupun ada responden yang menyatakan wujud kecenderungan pemilihan pemimpin berdasarkan kaum dan agama tertentu tetapi kecenderungan tersebut masih terlalu kecil. Ini bermakna isu kaum dan agama bukanlah satu isu yang besar dalam pemilihan pemimpin di kawasan Pantai Barat Sabah. Keadaan ini juga menggambarkan masyarakat pelbagai etnik dan agama di kawasan kajian yang terlibat tidak begitu mengambil kisah sesiapapun yang menjadi pemimpin mereka. Dapatan ini boleh ditafsirkan bahawa perkara yang paling penting adalah pemimpin yang dilantik perlu berkelayakan dalam mengetuai KRT dan melaksanakan pelbagai program yang baik untuk kepentingan penduduk. Selain itu, pemimpin KRT juga adalah pemimpin-pemimpin yang dilantik secara sukarela. Kesediaan pemimpin-pemimpin yang dilantik melakukan kerja-kerja sukarela dalam menguruskan dan melaksanakan pelbagai program di kawasan mereka memberikan nilai teladan dan moral kepada penduduk. Oleh yang demikian maka, kepimpinan KRT akan dihormati kerana beban tugas dan peranan mereka dilakukan secara sukarela tanpa sebarang bayaran gaji. Keadaan ini boleh jadi adalah antara penyebab penduduk tidak begitu mempersoalkan identiti kaum dan agama dalam pemilihan pemimpin KRT di kawasan mereka selain dipengaruhi oleh sifat toleransi yang tinggi dalam kalangan mereka. 


\section{Kesimpulan}

Kawasan Rukun Tetangga (KRT) yang dilaksanakan sejak tahun 1975 sehingga kini didapati memberikan kesan yang baik kepada masyarakat. Dapatan kajian ini menunjukkan hubungan antara penduduk semakin bertambah baik dengan adanya aktiviti KRT di sesuatu kawasan. Walaupun hubungan antara penduduk di sesuatu kawasan adalah baik dan harmoni tanpa penubuhan KRT, tetapi pelaksanaan KRT di sesuatu kawasan akan menjadi satu mekanisme atau medium untuk masyarakat menjalinkan hubungan dalam aktiviti seharian mereka, di samping mampu mengekalkan lagi keharmonian yang sedia ada. Oleh yang demikian, pelaksanaan KRT perlulah diberikan penekanan oleh pihak kerajaan untuk mempromosi dan menggalakkan penubuhan KRT di seluruh Malaysia. Selain itu, untuk menggalakkan penglibatan penduduk dalam aktiviti KRT peranan kerajaan dan badan bukan kerajaan serta pihak-pihak penaja sama ada individu mahupun syarikat tempatan perlu terlibat secara langsung agar aktiviti yang dilaksanakan akan lebih banyak dan memberi kesan yang baik kepada penduduk. Kesan tersebut bukan sahaja dari segi keselamatan tetapi juga melibatkan kepentingan ekonomi penduduk setempat.

\section{Penghargaan}

Manuskrip ini dihasilkan daripada geran penyelidikan Rukun Tetangga Dalam Konteks Kesepaduan Sosial: Kajian Kes Di Pantai Barat Sabah (SBK0347-2017) Universiti Malaysia Sabah.

\section{Rujukan}

Abdul Rahemang Taiming. (2018). KRT tingkat keselamatan keharmonian komuniti. Atas talian https://www.bharian.com.my/berita/wilayah/2018/02/383260/krt-tingkat-keselamatankeharmonian-komuniti. Diakses pada 17/10/2020.

Ahmad Zaharuddin Sani Ahmad Sabri, Nur Syafiqah Huda Mohd Rashidi. (2016). Penerimaan Masyarakat Terhadap Aktiviti Rukun Tetangga Mengikut Jantina. Jurnal Al-Hikmah, 8(2), 110127.

Bernama. (2009). Rukun Tetangga mampu tingkat kefahaman penduduk mengenai perpaduan. Atas talian https://www.mstar.com.my/lokal/semasa/2009/10/25/rukun-tetangga-mampu-tingkatkefahaman-penduduk-mengenai-perpaduan. Diekses pada 17/10/2020.

Bernama. (2019). Rukun Tetangga, persatuan penduduk, NGO tunjang perpaduan. Atas talian https://www.sinarharian.com.my/article/32804/EDISI/Sabah-Sarawak/Rukun-Tetanggapersatuan-penduduk-NGO-tunjang-perpaduan. Diakses pada 17/10/2020.

Budi Anto Mohd Tamring. (2008). Pengaruh Agama dalam Interaksi dan Toleransi Etnik: Kajian Kes ke atas Pelajar Bumiputera Sabah di Universiti Malaysia Sabah. Tesis Sarjana. Kota Kinabalu. Univertisi Malaysia Sabah. Tidak Diterbitkan.

Budi Anto Mohd Tamring. (2018). Mikorot Dalam Konteks Kebudayaan Etnik Dusun Di Sabah:Analisis Dari Perspektif Hubungan Etnik. MANU, 27, 93-120.

Budi Anto Mohd Tamring \& Saidatul Nornis Hj. Mahali. (2020). Amalan Kahwin Campur dalam kalangan Masyarakat Di Kota Kinabalu, Sabah. Malaysian Journal of Social Sciences and Humanities (MJSSH), 5(9), 149-162.

Budi Anto Mohd Tamring \& Saidatul Nornis Hj. Mahali. (2020). Hubungan Kaum di Sabah: Suatu Pemerhatian Awal. Malaysian Journal of Social Sciences and Humanities (MJSSH), 5(10), 95104.

Buku Tahunan Perangkaan Sabah (2014). Komposisi Etnik Mengikut Daerah di Sabah. Atas Talian http://www.malaysiaeconomy.net/download/18072016_1.pdf. Diakses pada 12/10/2020.

Chua, B. S., Jasmine Adela Mutang \& Lailawati Madlan. (2016). Persepsi Kumpulan Multietnik di Sabah terhadap Etnik Diri dan Etnik Lain. Jurnal MANU, 24, 111-145.

Clerence GD. (2019). KRT penting pupuk perpaduan dalam kalangan masyarakat. Harian Ekspres 21 Julai 2019. Atas Talian http://www.dailyexpress.com.my/news/138168/krt-penting-pupukperpaduan-dalam-kalangan-masyarakat/. Diakses pada 14/10/2020. 
Hamidah Abu Bakar. (2014). Kepimpinan Rukun Tetangga: Satu Kajian Kes di Kawasan Rukun Tetangga, Kampung Malaysia Raya, Cheras, Kuala Lumpur. Tesis Ijazah Sarjana Sains Kemasyarakatan. Bangi: UKM.

Jabatan Perpaduan Negara dan Integrasi Nasional (JPNIN). (2018). Senarai Kawasan Rukun Tetangga Di Kota Kinabalu dan Penampang. Kota Kinabalu. Jabatan Perpaduan Negara dan Integrasi Nasional.

Jabatan Perpaduan Negara dan Integrasi Nasional (JPNIN). (2020). Rukun Tetangga (RT). Atas Talian https://www.jpnin.gov.my/ms/komuniti/rukun-tetangga. Diakses pada 17/10/2020.

Mohammad Ishak. (2017). KRT Bandar Jertih contoh terbaik perpaduan kaum. Atas Talian https://www.bharian.com.my/berita/wilayah/2017/10/332430/krt-bandar-jertih-contoh-terbaikperpaduan-kaum. Diakses pada 17/10/2020.

Mohd Sohaimi Esa, Dayu Sansalu \& Budi Anto Mohd Tamring. (2011). Hubungan Etnik: Kelangsungan Pembinaan Negara Bangsa. Penerbitan Multimedia.

Mohd Sohaimi Esa, Budi Anto Mohd Tamring, Yusten Karulus, Mohd Azri Ibrahim, Dayu Sansalu, Siti Aidah Hj. Lokin \& Sharifah Darmia Sharif Adam. (2019). Rukun Tetangga dalam Konteks Kesepaduan Sosial Di Pantai Barat Sabah: Satu Tinjauan Awal. Prosiding Persidangan Serantau Peradaban dan Etnik (PERSEP 2019), 24-25 Oktober 2019.

Mohd Syariefudin Abdullah, Mansor Mohd Nor, Ahmad Rizal Mohd Yusof \& Faridah Che Hussain. (2017). Social Cohesion In Rukun Tetangga (Neighbourhood Watch) In Hulu Langat, Selangor Malaysia. E-bangi Journal of Social Sciences and Humanities. Special Issue 2.

Mohd Syariefudin Abdullah, Mazdi Marzuki, Mohd Marzuqi Abdul Rahim, Muhammad Akramin Kamarul Zaman \& Khairul Ghufran Kaspin. (2020). Penubuhan Rukun Tetangga Di Malaysia daripada Perspektif Islam. Tinta Artikulasi Membina Umah, 6(1), 99-111.

Mohd Syariefudin Abdullah, Mohd Mahadee Ismail, Mansor Mohd Noor (2013). Kesepaduan Sosial dan Kejiranan Di Kawasan Rukun Tetangga. Jurnal Kinabalu, 19, 66, 53-75.

Mohd. Taib Hj. Dora, Izaidin Abd. Majid, Raja Roslan Raja Abd. Rahman, Norliah Kudus, Zawiah Hj. Mat \& Noor Maslian Othman. (2008). City As An Urban Social Diversity: A Case Study Of Rukun Tetangga In Kuala Lumpur And Selangor. Journal of Human Capital Development. 1(1), $75-83$

Norwahidah Zinalibdin (2016). Makna rasa selamat komuniti Malaysia dalam Program Skim Rondaan Sukarela: Kajian kes KRT Taman Putera Jaya, Kota Kinabalu, Sabah. Malaysian Journal of Society and Space, 12(5), 22-32.

Sabihah Osman. Toleransi Etnik dan Perpaduan Sosial. Laporan Penyelidikan IRPA. Tidak Diterbitkan.

Saidatul Nornis Hj. Mahali. (2013). Nilai dan norma masyarakat di Sabah. Kota Kinabalu. Penerbit Universtiti Malaysia Sabah.

Sharifah Darmia Sharif Adam. (2019). Peranan Perkahwinan Campur Dalam Memupuk Hubungan Etnik Yang Harmoni di Sabah. Prosiding Persidangan Serantau Peradaban dan Etnik (PERSEP 2019), 24-25 Oktober 2019.

Suraya Sintang, Budi Anto Mohd Tamring, Nur Farhana Abdul Rahman, Siti Aidah Hj. Lukin \& Halina Sendera Mohd. Yakin. (2019). Kesepaduan Sosial dalam Hubungan antara Agama di Pedalaman Sabah. Borneo International Journal, 2(1), 5-15.

Suraya Sintang, Budi Anto Mohd Tamring \& Khadijah Mohd Hambali. (2016). Pattern of Intermarriage In Keningau: A Preliminary Study Towards Religious Tolerance. UMRAN Journal of Muslim Affairs, 2(1), 34-50. 